\title{
MAGNETIC SUSCEPTIBILITY IN THE PREDICTION OF SOIL ATTRIBUTES IN TWO SUGARCANE HARVESTING MANAGEMENT SYSTEMS
}

\section{RAFAEL G. PELUCO ${ }^{1}$, JOSÉ MARQUES JÚNIOR ${ }^{2}$, DIEGO S. SIQUEIRA ${ }^{3}$, LUCAS A. CORTEZ ${ }^{4}$, GENER T. PEREIRA ${ }^{5}$}

\begin{abstract}
This study aimed to investigate the potential use of magnetic susceptibility (MS) as pedotransfer function to predict soil attributes under two sugarcane harvesting management systems. For each area of 1 ha (one with green sugarcane mechanized harvesting and other one with burnt sugarcane manual harvesting), 126 soil samples were collected and subjected to laboratory analysis to determine soil physical, chemical and mineralogical attributes and for measuring of MS. Data were submitted to descriptive statistics by calculating the mean and coefficient of variation. In order to compare the means in the different harvesting management systems it was carried out the Tukey test at a significance level of 5\%. In order to investigate the correlation of the MS with other soil properties it was made the correlation test and aiming to assess how the MS contributes to the prediction of soil complex attributes it was made the multiple linear regressions. The results demonstrate that MS showed, in both sugarcane harvesting management systems, statistical correlation with chemical, physical and mineralogical soil attributes and it also showed potential to be used as pedotransfer function to predict attributes of the studied oxisol.
\end{abstract}

KEYWORDS: pedotransfer, indirect quantification, oxisol.

\section{SUSCETIBILIDADE MAGNÉTICA NA PREDIÇÃO DE ATRIBUTOS DO SOLO EM DOIS SISTEMAS DE MANEJO NA COLHEITA DE CANA DE AÇÚCAR}

RESUMO: O presente trabalho teve como objetivo investigar o potencial de uso da suscetibilidade magnética (SM) como componente da função de pedotransferência para predição de atributos do solo, sob dois sistemas de manejo na colheita de cana-de-açúcar. Para cada uma das duas áreas de 1 ha (uma com colheita mecanizada de cana crua e outra com colheita manual de cana queimada), foram coletadas 126 amostras de solo que foram submetidas às análises de laboratório, para determinação dos atributos físicos, químicos e mineralógicos do solo e para medição da SM. Os dados foram submetidos à estatística descritiva, calculando-se a média e o coeficiente de variação. Para comparar as médias nos diferentes sistemas de manejo, foi realizado o teste de Tukey, ao nível de significância de 5\%. Foram realizados o teste de correlação simples para averiguar a correlação da SM com outros atributos do solo e a regressão múltipla linear a fim de avaliar o quanto a SM contribui para a predição de atributos complexos do solo. Os resultados demonstram que a SM apresentou, em ambos os sistemas de manejo de colheita da cana-de-açúcar, correlação estatística com atributos químicos, físicos e mineralógicos do solo e apresentou potencial para ser utilizada como componente da função de pedotransferência para predição de atributos do Latossolo estudado.

PALAVRAS-CHAVE: pedotransferência, quantificação indireta, Latossolo.

\section{INTRODUCTION}

Mapping the spatial variability of soil attributes is of great importance for planning sustainable agricultural practices (BARBIERI et al., 2008). However, this type of study requires large numbers of samples, making the activity more costly and causing environmental impact due to

\footnotetext{
${ }^{1}$ Doutorando do PPG em Agronomia - Ciência do Solo; FCAV/UNESP Jaboticabal; rgpeluco@ hotmail.com.

${ }^{2}$ Prof. Adjunto do Dpto. de Solos e Adubos; FCAV/UNESP Jaboticabal; marques@ fcav.unesp.br.

${ }^{3}$ Pós-Doutorando do PPG em Agronomia - Ciência do Solo; FCAV/UNESP Jaboticabal; diego_silvasiqueira@yahoo.com.br.

${ }^{4}$ Mestre pelo PPG em Agronomia - Produção Vegetal; FCAV/UNESP Jaboticabal; cortez.lucas@ig.com.br.

${ }^{5}$ Prof. Adjunto do Dpto. de Ciências Exatas; FCAV/UNESP Jaboticabal; genertp@ fcav.unesp.br.

Recebido pelo Conselho Editorial em: 3-9-2012
}

Aprovado pelo Conselho Editorial em: 12-8-2013 
the use of chemical reagents in the laboratory. This fact is even more important in studies of the spatial variability of soil mineralogy, whose laboratory tests are expensive, time consuming and use many chemical reagents.

Some authors have proposed the use of pedotransfer functions, which are increasingly used in modern agriculture to indirectly estimate soil properties simply and quickly. According McBRATNEY et al. (2002) pedotransfer functions can be defined as mathematical models used to estimate the soil attributes from other attributes measured with greater ease and low cost.

An attribute that provides ease of measurement and can be used to indirectly determine soil properties is the magnetic susceptibility (MS) (GRIMLEY \& VEPRASKAS, 2000). MS is the result of the translation and rotation of the electrons which constitute some minerals that are present in soils, sediments and rocks (LUQUE, 2008), may also be defined as the degree of magnetization of a material in response to an applied magnetic field. The materials may have five different types of magnetic behavior: ferromagnetic, ferrimagnetic, ant ferromagnetic, paramagnetic and diamagnetic (COEY, 1988).

Minerals can have its formation, stability and consequently its magnetism changed as the management is carried out in the soil, for example in green and burnt harvesting systems of sugarcane. Sugarcane burning provides the elevation of soil temperature, and according to HANESH et al. (2006) high temperatures promote the transformation of pedogenic Fe, causing the formation of minerals with magnetic feature.

According to MATHÉ et al. (2006) the magnetic minerals can be considered as micro markers of the soil properties, since the crystallographic properties of these minerals reflect the factors and processes of soil formation (MAHER \& THOMPSON, 1999), which are specific for each location. Therefore, the MS is shown a promising tool for mapping these sites, especially in tropical soils. RESENDE et al. (1988), performing measurements of MS found variation in magnetic behavior of different classes of soils with $\mathrm{Fe}_{2} \mathrm{O}_{3}$ ranging from $3 \%$ to $30 \%$.

The measures of MS can be performed in the laboratory or in the field and can be used to complement other types of environmental analyzes. Most of the works presented on MS, in the field of soil science, uses its own sensors (BARTINGTON INSTRUMENTS, WITNEY, UK) (DEARING, 1999; PREETZ et al., 2008). Other authors evaluated the MS through the system developed by RANKINE (1934) and improved by DAVIS (1992) using an analytical balance (CARNEIRO et al., 2003; CANO et al., 2008; SIQUEIRA et al., 2010) and magnetometer (FABRIS et al. 1998). The advantage of using the analytical balance method is simplicity, allowing its use by researchers and producers of different levels of technical standards.

Recent studies demonstrate the potential of pedotransfer functions using the MS for indirect quantification of clay content, base saturation, soil content of hematite ( SIQUEIRA et al., 2010) susceptibility to erosion (SANTOS et al., 2011) and qualitative and quantitative potential of the soil for the cultivation of oranges (CORTEZ et al., 2011). This information about the potential use and applications of MS are important to encourage further research on the topic.

The objective of this study was to investigate the potential of MS as a component of pedotransfer function for predicting attributes of an oxisol in two harvesting tillage systems on sugarcane crop.

\section{MATERIAL AND METHODS}

The study areas are located in the northeast of São Paulo State, in the municipality of Guariba. The geographical coordinates are $21^{\circ} 19^{\prime}$ 'south latitude and $48^{\circ} 13^{\prime}$ west longitude, with an average altitude of $640 \mathrm{~m}$ above sea level.

The climate of the region, according to the Köppen classification, is the type mega thermal, tropical with dry season in the winter (Aw) and average rainfall of $1,400 \mathrm{~mm}$, with rainfall 
concentrated in the period from November to February. Natural vegetation was consisted tropical semi deciduous forest.

These areas are in the geomorphic provinces of the Western Paulista Plateau near the boundary of the Basaltic Cuesta splitter lithostratigraphic sandstone-basalt. The soils of the areas were classified as Oxisol, very clayey (LVef) (EMBRAPA, 2006) under cultivation of sugar cane, being an area with burnt cane harvesting, and an area with green cane harvesting, both areas with more than 10 years with this type of management (Figure 1).

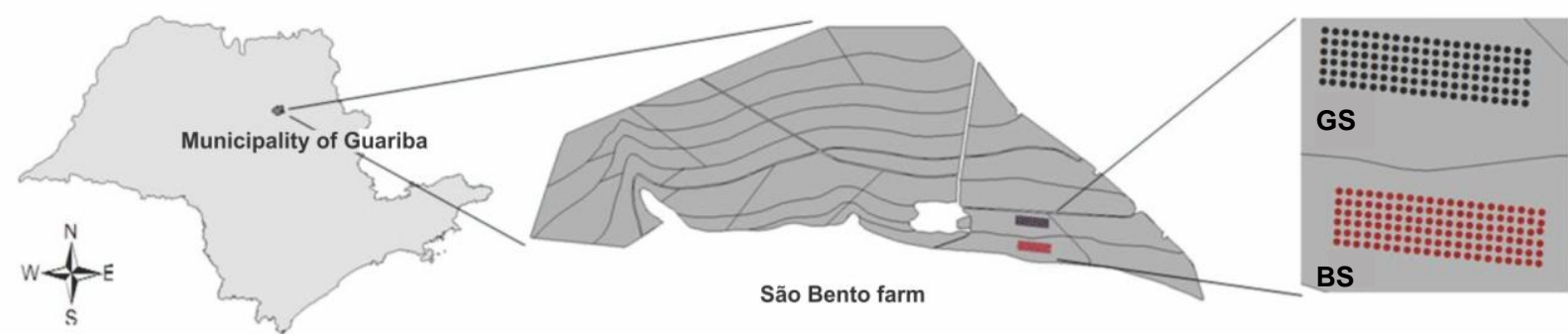

FIGURE1. Location areas; area with mechanized harvesting system of green sugarcane (GS) and area with manual harvesting system of burnt sugarcane (BS).

Samples were collected at depth of 0.00-0.20 m, in two areas of 1 ha each $(200 \times 50 \mathrm{~m})$, with intervals of $10 \mathrm{~m}$, totaling 126 points in each area. The samples were taken to characterize the iron oxides clay, chemical analysis and physical measurements of soil magnetic susceptibility.

The samples were dried and part of them passed through a strainer of $9.51 \mathrm{~mm}$ mesh size for evaluation of soil aggregation, and the remainder passed through a strainer of $2.0 \mathrm{~mm}$ mesh size for granulometric, chemical and mineralogical analysis. The separation and aggregate stability were determined by the method described by KEMPER \& CHEPIL (1965). The aggregates were placed in contact with water in a strainer of $4.76 \mathrm{~mm}$ mesh size, for fifteen minutes, the mass of material retained on each strainer was placed in an oven at $105{ }^{\circ} \mathrm{C}$. The results obtained were used to calculate the percentage of aggregates with diameter greater than $2 \mathrm{~mm}$ in the range of 1-2 $\mathrm{mm}$ and to less than $1 \mathrm{~mm}$.

The particle size was determined according to the Stokes Law, by the pipette method with $\mathrm{NaOH} 0.1 \mathrm{~mol}_{\mathrm{c}} \mathrm{L}^{-1}$ as chemical dispersant and mechanical stirring apparatus at low speed for 16 hours, following the methodology proposed by EMBRAPA (1997). Soil porosity (total pore volume - TPV macrospores and microspores) was determined by the method proposed by EMBRAPA (1997). Soil bulk density was determined by the method of known volume in volumetric rings (EMBRAPA, 1997). The water content of the soil was determined gravimetrically (GARDNER, 1986).

The determination of soil chemical properties $\left(\mathrm{pH}, \mathrm{Ca}^{+}{ }^{+}, \mathrm{Mg}^{++}, \mathrm{K}^{+}\right.$, and $\mathrm{H}+\mathrm{Al}$ ), calculations of sum of bases (SB), the cationic exchange capacity (CEC), the index base saturation (V\% ) and the determination of phosphorus was conducted according to RAIJ et al. (2001). The content of organic matter (OM) was obtained according to the method described in EMBRAPA (1997). Minerals hematite and goethite were determined according to the methodology described by CAMARGO et al. (2008a).

MS samples were measured by a sensor Bartington Instruments (DEARING, 1999) and a precision balance according to the methodology described by CANO et al. (2008) and SIQUEIRA et al. (2010) (Figure 2). 


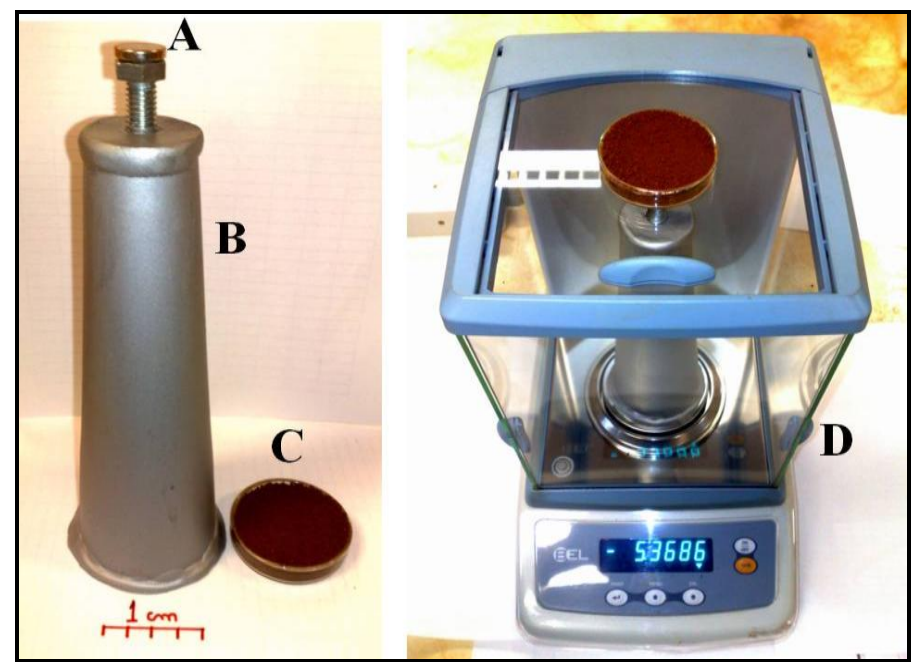

FIGURE 2. A. Imam; B. Support; C. Sample port; D. Set imam - support - sample port and scale (equipment used by SIQUEIRA et al. (2010) adapted from CARNEIRO et al. (2003).

Data were statistically analyzed, obtaining the average and coefficient of variation. To compare the averages in different management systems a Tukey test was conducted at a significance level of $5 \%$.

In order to investigate the correlation of MS with other soil properties, the correlation test was performed. Multiple linear regression was also performed in order to assess the extent to how much the MS contributes to the prediction of complex attributes of the soil. This type of analysis involves three or more variables called "predicted" and a variable named "predictor". In case the attribute MS was correlated with a set of soil properties, according to Equation (1).

$$
\mathrm{Y}=\mathrm{a}+\mathrm{b}_{1} \mathrm{x}_{1}+\mathrm{b}_{2} \mathrm{x}_{2}+\ldots+\mathrm{B}_{\mathrm{k}} \mathrm{x}_{\mathrm{k}}
$$

In which

a - the intercept of the y axis;

$b_{i}$ - angular coefficient of the i-th variable;

$\mathrm{k}$ - Number of independent variables.

The multiple regression analysis was carried out in the software MINITAB ${ }^{\circledR}$ Release 14.1

\section{RESULTS AND DISCUSSION}

Several attributes significantly differed by Tukey test, when they were compared between the two harvesting management systems with the exception of the average diameter of the particle, aggregates larger than $2 \mathrm{~mm}$, aggregates between 1 and $2 \mathrm{~mm}$, aggregates smaller than $1 \mathrm{~mm}$, density, microspores, organic matter, available and adsorbed phosphorus, isomorphic substitution of goethite and hematite and goethite content (Table 1). CARVALHO et al. (2012) also found influence of sugarcane harvesting management systems in physical attributes of an Oxisol.

Analyzing the attribute MS, there is greater coefficient of variation in the area of green sugarcane $(15.16 \%)$ compared to the area of burnt cane, whose MS variation coefficient was $14.88 \%$. This shows greater variability of this attribute in the area of green sugarcane. According to the criteria proposed by WARRICK \& NIELSEN (1980), in both study areas MS presented moderate coefficient of variation $(\mathrm{CV} \leq 12 \% \leq 52 \%)$.

In the area of green sugarcane the average value of MS $\left(4.5910^{-6} \mathrm{~m}^{3} \mathrm{~kg}^{-1}\right)$ was higher than the value of the area burnt cane $\left(4.1910^{-6} \mathrm{~m}^{3} \mathrm{~kg}^{-1}\right)$, presenting a significant difference. Organic matter showed no significant difference between the two study areas. These results are contrary to those found by SCHWERTMANN (1988) and HANESCH et al. (2006), who reported that high temperatures and organic matter favors the transformation on pedogenic Fe, causing the formation of new minerals with magnetic feature. 
TABLE 1. Statistics for soil attributes, on green and burnt sugarcane areas.

\begin{tabular}{|c|c|c|c|c|c|c|c|}
\hline \multirow{2}{*}{\multicolumn{2}{|c|}{ Soil Attributes }} & \multicolumn{3}{|c|}{ Green Sugarcane } & \multicolumn{3}{|c|}{ Burnt Sugarcane } \\
\hline & & Average & & $\mathrm{CV} \%$ & Average & & CV\% \\
\hline MS & $\mathrm{m}^{3} \mathrm{~kg}^{-1}$ & $4.5910^{-6}$ & $\mathrm{a}$ & 15.16 & $4.1910^{-6}$ & $\mathrm{~b}$ & 14.88 \\
\hline Clay & $\mathrm{g} \mathrm{kg}^{-1}$ & 635.47 & $\mathrm{a}$ & 24.80 & 614.3 & $\mathrm{~b}$ & 2.17 \\
\hline Silte & $\mathrm{g} \mathrm{kg}^{-1}$ & 74.96 & $\mathrm{a}$ & 24.48 & 58.01 & $\mathrm{~b}$ & 23.94 \\
\hline TS & $\mathrm{g} \mathrm{kg}^{-1}$ & 288.60 & $\mathrm{a}$ & 7.33 & 327.80 & $b$ & 5.12 \\
\hline $\mathrm{CS}$ & $\mathrm{g} \mathrm{kg}^{-1}$ & 20.80 & $\mathrm{a}$ & 12.11 & 27.17 & $\mathrm{~b}$ & 12.28 \\
\hline AS & $\mathrm{g} \mathrm{kg}^{-1}$ & 78.08 & $\mathrm{a}$ & 8.18 & 85.21 & $\mathrm{~b}$ & 5.58 \\
\hline FS & $\mathrm{g} \mathrm{kg}^{-1}$ & 125.58 & $\mathrm{a}$ & 7.32 & 148.63 & $\mathrm{~b}$ & 7.20 \\
\hline VFS & $\mathrm{g} \mathrm{kg}^{-1}$ & 60.41 & $\mathrm{a}$ & 9.48 & 63.22 & $\mathrm{~b}$ & 6.97 \\
\hline ADP & $\mathrm{mm}$ & 2.79 & $\mathrm{a}$ & 15.89 & 2.71 & $\mathrm{a}$ & 18.84 \\
\hline Agr. $>2 \mathrm{~mm}$ & $\%$ & 60.96 & $\mathrm{a}$ & 22.04 & 59.33 & $\mathrm{a}$ & 28.40 \\
\hline Agr. 1_2 mm & $\%$ & 18.30 & $\mathrm{a}$ & 39.25 & 18.18 & $\mathrm{a}$ & 50.87 \\
\hline Agr. $<1 \mathrm{~mm}$ & $\%$ & 20.81 & $\mathrm{a}$ & 45.73 & 22.23 & $\mathrm{a}$ & 38.18 \\
\hline Ds & $\%$ & 1.28 & $\mathrm{a}$ & 5.41 & 1.31 & $\mathrm{a}$ & 10.08 \\
\hline Macropores & $\%$ & 13.50 & $\mathrm{a}$ & 31.01 & 10.72 & $\mathrm{~b}$ & 51.84 \\
\hline Micropores & $\%$ & 36.71 & $\mathrm{a}$ & 7.43 & 36.15 & $\mathrm{a}$ & 7.47 \\
\hline TPV & $\%$ & 50.17 & $\mathrm{a}$ & 6.15 & 46.89 & $\mathrm{~b}$ & 9.22 \\
\hline MSS & $\%$ & 28.84 & $\mathrm{a}$ & 8.62 & 27.73 & $\mathrm{~b}$ & 9.61 \\
\hline $\mathrm{H}+\mathrm{Al}$ & mmolc $\mathrm{dm}^{-3}$ & 36.96 & a & 18.50 & 30.24 & b & 18.24 \\
\hline $\mathrm{K}^{+}$ & mmolc $\mathrm{dm}^{-3}$ & 1.42 & $\mathrm{a}$ & 49.18 & 3.15 & $\mathrm{~b}$ & 38.11 \\
\hline $\mathrm{Ca}^{++}$ & mmolc dm $\mathrm{dm}^{-3}$ & 27.67 & $\mathrm{a}$ & 25.92 & 43.05 & $\mathrm{~b}$ & 15.57 \\
\hline $\mathrm{Mg}^{++}$ & mmolc $\mathrm{dm}^{-3}$ & 8.31 & $\mathrm{a}$ & 28.61 & 9.41 & $\mathrm{~b}$ & 19.46 \\
\hline SB & mmolc $\mathrm{dm}^{-3}$ & 37.52 & $\mathrm{a}$ & 25.02 & 54.85 & $\mathrm{~b}$ & 21.05 \\
\hline $\mathrm{V} \%$ & $\%$ & 49.96 & $\mathrm{a}$ & 18.85 & 65.19 & $\mathrm{~b}$ & 8.39 \\
\hline M.O. & $\mathrm{g} \mathrm{dm}^{-3}$ & 24.33 & $\mathrm{a}$ & 3.53 & 24.45 & $\mathrm{a}$ & 0.36 \\
\hline CTC & mmolc $\mathrm{dm}^{-3}$ & 74.90 & $\mathrm{a}$ & 8.86 & 86.00 & $\mathrm{~b}$ & 0.96 \\
\hline $\mathrm{pH}$ & & 4.86 & $\mathrm{a}$ & 4.84 & 5.28 & $\mathrm{~b}$ & 4.20 \\
\hline available P & $\mathrm{mg} \mathrm{dm}^{-3}$ & 81.18 & $\mathrm{a}$ & 3.85 & 79.60 & $\mathrm{a}$ & 8.50 \\
\hline $\mathrm{P}$ adsorbed & $\mathrm{mg} \mathrm{kg}^{-1}$ & 376.31 & $\mathrm{a}$ & 77.06 & 407.85 & $\mathrm{a}$ & 170.00 \\
\hline Peak area Hm & $\mathrm{cm} 2$ & 0.67 & $\mathrm{a}$ & 26.56 & 0.84 & $\mathrm{~b}$ & 22.30 \\
\hline Peak area Gt & $\mathrm{cm} 2$ & 0.25 & $\mathrm{a}$ & 31.06 & 0.49 & $\mathrm{~b}$ & 47.33 \\
\hline WHH Hm & ${ }^{\circ} 2 \theta$ & 0.3753 & $\mathrm{a}$ & 0.03 & 0.3700 & $\mathrm{~b}$ & 5.91 \\
\hline WHH Gt & ${ }^{\circ} 2 \theta$ & 0.4567 & $\mathrm{a}$ & 18.94 & 0.5500 & $\mathrm{~b}$ & 12.45 \\
\hline ADC Hm & $\mathrm{Nm}$ & 53.93 & $\mathrm{a}$ & 0.09 & 57.27 & $\mathrm{~b}$ & 18.62 \\
\hline $\mathrm{ADC} G \mathrm{t}$ & $\mathrm{Nm}$ & 41.34 & $\mathrm{a}$ & 45.23 & 28.23 & $\mathrm{~b}$ & 30.57 \\
\hline IS Hm & $\mathrm{mol} \%$ & 14.55 & $\mathrm{a}$ & 21.45 & 14.49 & $\mathrm{a}$ & 30.43 \\
\hline SI Gt & $\mathrm{mol} \%$ & 24.80 & $\mathrm{a}$ & 26.03 & 26.06 & $\mathrm{a}$ & 28.64 \\
\hline Hm level & $\mathrm{g} \mathrm{kg}^{-1}$ & 167.90 & $\mathrm{a}$ & 7.58 & 115.30 & $\mathrm{~b}$ & 15.84 \\
\hline Gt level & $\mathrm{g} \mathrm{kg}^{-1}$ & 25.70 & $\mathrm{a}$ & 38.96 & 26.70 & $\mathrm{a}$ & 43.70 \\
\hline Ratio Gt / Gt + Hm & & 0.12 & $\mathrm{a}$ & 29.80 & 0.17 & $\mathrm{~b}$ & 44.61 \\
\hline
\end{tabular}

TS = Total Sand; CS = Coarse Sand; AS = Average Sand; AF = Fine Sand; VFS = Very Fine Sand; ADP = Average Diameter Particle; Agr. $>=2 \mathrm{~mm}$ aggregate class greater than $2 \mathrm{~mm}$ high; Agr.1_2 $\mathrm{mm}=$ class aggregates between 1 and $2 \mathrm{~mm}$ high; Agr. <1 $\mathrm{mm}=$ class aggregates Smaller than $1 \mathrm{~mm}, \mathrm{CV}=$ coefficient of variation, DS = Density of Soil; TPV = Total Pore Volume, MSS = mass Soil Moisture, $\mathrm{SB}=$ Sum of bases, $\mathrm{V}=\%$ saturation by bases, $\mathrm{OM}=$ organic matter, $\mathrm{CEC}=$ Cationic Exchange Capacity; LMA $=$ Width at Half Height, $\mathrm{ADC}=$ Average Diameter of Crystal, $\mathrm{IS}=$ isomorphic substitution; $\mathrm{Hm}=$ Hematite, Goethite Gt $=$, MS = Magnetic Susceptibility; * significant at $5 \%$ probability $(\mathrm{p}<0,05)$. Averages shown with different letters in the line differ by Tukey test at $5 \%$.

The higher content of MS in the area of sugarcane can be related, in this case, to the clay content. The area of sugarcane showed higher average clay content compared to sugarcane area burned (Table 1). FONTES et al. (2000) mentioned that the magnetic behavior is in fact more evident in soils whose clay fraction is bigger because in clay, magnetite is oxidized to maghemite, while in the sand fraction; magnetite is oxidized directly to hematite that has lower MS than magnetite.

In the area of raw sugarcane correlation of MS with clay and silt, total sand, thick sand, medium sand, fine sand, very fine sand, soil bulk density, macro porosity, micro porosity, total porosity, and soil moisture mass content of hematite (Table 2). 
TABLE 2. Correlation of magnetic susceptibility with soil attributes in green and burnt sugarcane areas.

\begin{tabular}{|c|c|c|c|c|c|c|c|c|}
\hline \multicolumn{9}{|c|}{ Raw Sugarcane } \\
\hline \multicolumn{3}{|c|}{ Physical Attributes } & \multicolumn{2}{|c|}{ Chemical attributes } & \multicolumn{4}{|c|}{ Mineralogical attributes } \\
\hline clay & $\mathrm{g} \mathrm{kg}^{-1}$ & $0.325 * *$ & $\mathrm{H}+\mathrm{Al}$ & mmolc dm ${ }^{-3}$ & $0.115^{\mathrm{ns}}$ & Peak area $\mathrm{Hm}$ & $\mathrm{m}^{2}$ & $0.081^{\mathrm{ns}}$ \\
\hline silt & $\mathrm{g} \mathrm{kg}^{-1}$ & $0.323 * *$ & $\mathrm{~K}^{+}$ & mmolc dm ${ }^{-3}$ & $-0.070^{\mathrm{ns}}$ & Peak area Gt & $\mathrm{m}^{2}$ & $0.054^{\mathrm{ns}}$ \\
\hline TA & $\mathrm{g} \mathrm{kg}^{-1}$ & $-0.609 * *$ & $\mathrm{Ca}^{++}$ & mmolc dm ${ }^{-3}$ & $-0.077^{\mathrm{ns}}$ & LMA Hm & $2 \theta$ & $-0.144^{\mathrm{ns}}$ \\
\hline $\mathrm{CS}$ & $\mathrm{g} \mathrm{kg}^{-1}$ & $-0.441 * *$ & $\mathrm{Mg}^{++}$ & mmolc dm ${ }^{-3}$ & $0.003^{\mathrm{ns}}$ & LMA Gt & $2 \theta$ & $-0.056^{\mathrm{ns}}$ \\
\hline AS & $\mathrm{g} \mathrm{kg}^{-1}$ & $-0, .50 * *$ & SB & mmolc dm ${ }^{-3}$ & $-0.101^{\mathrm{ns}}$ & DMC Hm & $\mathrm{m}$ & $0.144^{\mathrm{ns}}$ \\
\hline FS & $\mathrm{g} \mathrm{kg}^{-1}$ & $-0.572 * *$ & $\mathrm{~V} \%$ & $\%$ & $-0.091^{\mathrm{ns}}$ & DMC Gt & $\mathrm{m}$ & $0.098^{\mathrm{ns}}$ \\
\hline VFS & $\mathrm{g} \mathrm{kg}^{-1}$ & $-0.393 * *$ & M.O. & $\mathrm{g} \mathrm{dm}^{-3}$ & $-0.063^{\mathrm{ns}}$ & SI Hm & $\mathrm{ol} \%$ & $-0.090^{\mathrm{ns}}$ \\
\hline ADP & $\mathrm{mm}$ & $0.091^{\mathrm{ns}}$ & CTC & mmolc dm ${ }^{-3}$ & $0.058^{\mathrm{ns}}$ & $\mathrm{SI} \mathrm{Gt}$ & $\mathrm{ol} \%$ & $0.140^{\mathrm{ns}}$ \\
\hline Agr. $>2 \mathrm{~mm}$ & $\%$ & $0.034^{\mathrm{ns}}$ & $\mathrm{pH}$ & & $-0.093^{\mathrm{ns}}$ & Teor Hm & $\mathrm{kg}^{-1}$ & $0.422 * *$ \\
\hline Agr. 1_2 mm & $\%$ & $0.168^{\mathrm{ns}}$ & $\mathrm{P}$ available & $\mathrm{mg} \mathrm{dm} \mathrm{m}^{-3}$ & $0.013^{\mathrm{ns}}$ & Teor Gt & $\mathrm{kg}^{-1}$ & $-0.099^{\mathrm{ns}}$ \\
\hline Agr. $<1 \mathrm{~mm}$ & $\%$ & $-0.155^{\mathrm{ns}}$ & $\mathrm{P}$ adsorbed & $\mathrm{mg} \mathrm{kg}^{-1}$ & $0.059^{\mathrm{ns}}$ & $\begin{array}{l}\text { Ratio Gt / Gt + } \\
\mathrm{Hm}\end{array}$ & & $-0.167^{\mathrm{ns}}$ \\
\hline DS & $\%$ & $-0.439 * *$ & & & & & & \\
\hline macropores & $\%$ & $0.358^{* *}$ & & & & & & \\
\hline micropores & $\%$ & $-0.239 * *$ & & & & & & \\
\hline TPV & $\%$ & $0.409 * *$ & & & & & & \\
\hline MSM & $\%$ & $0.221 *$ & & & & & & \\
\hline
\end{tabular}

Burnt Sugarcane

\begin{tabular}{|c|c|c|c|c|c|c|c|c|}
\hline \multicolumn{3}{|c|}{ Physical Attributes } & \multicolumn{3}{|c|}{ Chemical attributes } & \multicolumn{3}{|c|}{ Mineralogical attributes } \\
\hline clay & $\mathrm{g} \mathrm{kg}^{-1}$ & $0.034^{\mathrm{ns}}$ & $\mathrm{H}+\mathrm{Al}$ & mmolc dm ${ }^{-3}$ & $-0.303 * *$ & Peak area Hm & $\mathrm{m}^{2}$ & $0,076^{\mathrm{ns}}$ \\
\hline Silt & $\mathrm{g} \mathrm{kg}^{-1}$ & $0.323 * *$ & $\mathrm{~K}^{+}$ & mmolc dm ${ }^{-3}$ & $0.148^{\mathrm{ns}}$ & Peak area Gt & $\mathrm{m}^{2}$ & $-0.127^{\mathrm{ns}}$ \\
\hline $\mathrm{TA}$ & $\mathrm{g} \mathrm{kg}^{-1}$ & $-0.303 * *$ & $\mathrm{Ca}^{++}$ & mmolc $\mathrm{dm}^{-3}$ & $-0.094^{\mathrm{ns}}$ & LMA Hm & $2 \theta$ & $-0.047^{\mathrm{ns}}$ \\
\hline CS & $\mathrm{g} \mathrm{kg}^{-1}$ & $-0.003^{\mathrm{ns}}$ & $\mathrm{Mg}^{++}$ & mmolc dm ${ }^{-3}$ & $0.036^{\mathrm{ns}}$ & LMA Gt & $2 \theta$ & $-0.278 * *$ \\
\hline AS & $\mathrm{g} \mathrm{kg}^{-1}$ & $-0.166^{\mathrm{ns}}$ & SB & mmolc $\mathrm{dm}^{-3}$ & $-0.004^{\mathrm{ns}}$ & DMC Hm & $\mathrm{m}$ & $0.104^{\mathrm{ns}}$ \\
\hline FS & $\mathrm{g} \mathrm{kg}^{-1}$ & $-0.338 * *$ & $\mathrm{~V} \%$ & $\%$ & $0.099^{\mathrm{ns}}$ & DMC Gt & $\mathrm{m}$ & $0.212 *$ \\
\hline VFS & $\mathrm{g} \mathrm{kg}^{-1}$ & $-0.174^{\mathrm{ns}}$ & M.O. & $\mathrm{g} \mathrm{dm}^{-3}$ & $-0.022^{\mathrm{ns}}$ & SI Hm & $\mathrm{ol} \%$ & $0.121^{\mathrm{ns}}$ \\
\hline ADP & $\mathrm{mm}$ & $-0.133^{\mathrm{ns}}$ & CTC & mmolc $\mathrm{dm}^{-3}$ & $-0.180^{\mathrm{ns}}$ & SI Gt & $\mathrm{ol} \%$ & $0.020^{\mathrm{ns}}$ \\
\hline Agr. $>2 \mathrm{~mm}$ & $\%$ & $-0.147^{\mathrm{ns}}$ & $\mathrm{pH}$ & & $0.202 *$ & Teor Hm & $\mathrm{kg}^{-1}$ & $0.17^{\mathrm{ns}}$ \\
\hline Agr. 1_2 mm & $\%$ & $0.160^{\mathrm{ns}}$ & $\mathrm{P}$ availablel & $\mathrm{mg} \mathrm{dm}^{-3}$ & $0.221 * *$ & Teor Gt & $\mathrm{kg}^{-1}$ & $-0.099^{\mathrm{ns}}$ \\
\hline Agr. $<1 \mathrm{~mm}$ & $\%$ & $0.108^{\mathrm{ns}}$ & $\mathrm{P}$ adsorbed & $\mathrm{mg} \mathrm{kg}^{-1}$ & $-0.240 * *$ & & & $-0.167^{\mathrm{ns}}$ \\
\hline DS & $\%$ & $-0.427 * *$ & & & & & & \\
\hline macropores & $\%$ & $0.367 * *$ & & & & & & \\
\hline micropores & $\%$ & $-0.222 * *$ & & & & & & \\
\hline TPV & $\%$ & $0.375^{* *}$ & & & & & & \\
\hline MSM & $\%$ & $0.296 * *$ & & & & & & \\
\hline
\end{tabular}


In the area of burning sugarcane, the correlation of MS was found with silt content, total sand, fine sand, soil bulk density, macro porosity, micro porosity, total porosity, soil moisture mass, $\mathrm{H}+$ $\mathrm{Al}, \mathrm{pH}$, available phosphorus, adsorbed phosphorus, half width of goethite and average of the crystal diameter of goethite. HANESCH \& SCHOLGER (2005) also found significant correlations of MS with physical and chemical properties of soils. As the physical and chemical soil characteristics are reflections of mineralogical (HEREDIA \& CIRELLI, 2007; CAMARGO et al., 2008 b), MS can be used as an indirect measure of these attributes in soils that have magnetic expression.

It is noteworthy, in the area of raw sugarcane, the correlation of MS with the total sand content $(\mathrm{r}=-0.609 * *)$ and hematite content of soil $(\mathrm{r}=0.422 * *)$ in burnt sugarcane area is worth mentioning the MS correlation with the total pore volume $\left(\mathrm{r}=0.375^{* *}\right), \mathrm{H}+\mathrm{Al}(\mathrm{r}=-0.303 * *)$ and half width of goethite $(\mathrm{r}=-0.278 * *)$. In the area of raw sugarcane there was correlation of $0.422 * *$ between MS and hematite content, indicating that MS is higher in places with higher content of hematite. In the area of burnt sugarcane was not found the correlation above.

Other authors (CHEVRIER \& MATHÉ 2007; TORRENT et al., 2007) also report on the relationship of MS with mineralogical attributes. Second (KÄMPF \& CURI, 2000), iron oxides are important indicators of environmental conditions. These minerals are abundant in tropical soils and have strong expression in the magnetic behavior of some classes solo MS shows up as a promising measure qualitative and quantitative mapping to assist in specific areas of management in certain agricultural areas of Brazil.

Because of the complexity of determining attributes of some soil it could be observed by the use of multiple linear regression (Table3), some examples of how MS combined with other methods could contribute to reducing the time and cost of soil analysis and upon further research, contribute to a possible reduction of laboratory error. In Brazil, there are frequent misunderstandings laboratory, reaching ranges of 3-26\% error in chemical analysis for determining macronutrients and $15-32 \%$ for analysis of grain size (CANTARELLA et al., 2006).

It was found in the determination of hematite in sugarcane area, through the average particle diameter and density, that the MS was added $13.3 \%$ can explain the content of the hematite more than when it was performed regression without MS. The same was observed in the determination of hematite in the area of raw cane, by $\%$ of aggregates larger than $2 \mathrm{~mm}$, and organic matter content of soil. When added in explaining MS increased from $13.4 \%$ (Table 3).

SCHWERTMANN \& TAYLOR (1989) cited the different iron oxides which may occur in the soil and its characteristics, stating that goethite and hematite minerals are most frequent in weathered soils of tropical and subtropical regions and usually occur associated. It is noteworthy that hematite is major clay minerals in Brazilian Oxisols and that too affects the behavior of the physical and chemical properties of soils (FERREIRA et al., 1999; PEDROTTI et al., 2003).

TABLE 3. Multiple linear regressions.

\begin{tabular}{|c|c|c|}
\hline Area & Equation & $\mathrm{r}^{2}$ \\
\hline RSC without MS & $\% \mathrm{Hm}=215-8.52 \mathrm{dmp}-17,9 \mathrm{Ds}$ & 0.063 \\
\hline RSC with MS & $\% \mathrm{Hm}=129-5.03 \mathrm{dmp}+12,1 \mathrm{Ds}+828472 \mathrm{MS}$ & 0.196 \\
\hline RSC without MS & $\% \mathrm{Hm}=193-0.242 \%$ Agregados $>2-0.388 \mathrm{OM}$ & 0.070 \\
\hline RSC with MS & $\% \mathrm{Hm}=151-0.179 \%$ Agregados $>2-0.212 . \mathrm{OM} .+738714 \mathrm{MS}$ & 0.204 \\
\hline BSC without MS & $\mathrm{CTC}=504-0.473 \mathrm{Arg}-0.43 \mathrm{Sil}+0.646 \mathrm{At}-0.574 \mathrm{Ag}-1.37 \mathrm{Am}-0.489 \mathrm{Af}-1.70 \mathrm{Amf}$ & 0.347 \\
\hline BSC with MS & $\mathrm{CTC}=533-0.505 \mathrm{Arg}-0.422 \mathrm{Sil}+0.762 \mathrm{At}-1.08 \mathrm{Ag}-1.45 \mathrm{Am}-0.588 \mathrm{Af}-1.86 \mathrm{Amf}-42561 \mathrm{MS}$ & 0.451 \\
\hline BSC without MS & LMA Gt $=0.515+0.000348 \%$ Agregados $>2+0.00065 . \mathrm{OM}$ & 0.011 \\
\hline BSC with MS & LMA Gt $=0.612+0.000289 \%$ Agregados $>2+0.00137$. OM. $-2650 \mathrm{MS}$ & 0.091 \\
\hline
\end{tabular}

In the area of burnt sugarcane this fact was also observed, with an improvement in the explanation of $10.4 \%$ when added to the MS in the determination of CTC (important attribute in the 
characterization of production environments for cane sugar) through content of clay, silt and sand fractions (Table 3). Also in the burnt sugarcane, estimating the LMA goethite, from the percentage of aggregates larger than $2 \mathrm{~mm}$ and organic matter content was obtained after adding the MS, an increase of $8 \%$. Pointing out that the goethite is considered by many authors as the main component of iron oxide clay responsible for adsorption of phosphorus been a complicated laboratory determination (JOHNSON \& LOEPPERT, 2006; ULÉN \& SNÄLL; 2007; HEREDIA \& CIRELLI 2007). JOHNSON \& LOEPPERT, 2006; ULÉN \& SNÄLL, 2007; HEREDIA \& CIRELLI 2007).

Results obtained to determine the MS can be indicated as a promising alternative technique to assist in the indirect quantification of soil attributes that have magnetic expression. This indicates the need for further research and further studies on the subject. According to HARTEMINK (2007), the scenario coming of soil science is moving towards the use of pedotransfer functions.

\section{CONCLUSIONS}

The magnetic susceptibility presented in both management systems for sugarcane harvesting , statistical correlation with the chemical, physical and mineralogical characteristics of the soil and the potential to be used as a component of pedotransfer function for predicting attributes of oxisol study.

\section{REFERENCES}

BARBIERI, D. M; MARQUES JUNIOR, J.; PEREIRA, G. T. Variabilidade espacial de atributos químicos de um argissolo para aplicação de insumos à taxa variável em diferentes formas de relevo. Engenharia Agrícola, Jaboticabal, v.28, n.4, p.645-653, 2008.

CAMARGO, L. A.; MARQUES JÚNIOR, J.; PEREIRA, G. T.; HORVAT, R. A. Variabilidade espacial de atributos mineralógicos de um latossolo sob diferentes formas do relevo. I - Mineralogia da fração argila. Revista Brasileira de Ciência do Solo, Viçosa-MG, v.32, p.2269-2277, 2008(a).

CAMARGO, L. A.; MARQUES JÚNIOR, J.; PEREIRA, G. T.; HORVAT, R. A. Variabilidade espacial de atributos mineralógicos de um latossolo sob diferentes formas do relevo. II - Correlação espacial entre mineralogia e agregados. Revista Brasileira de Ciência do Solo, Viçosa-MG, v.32, p.2279-2288, 2008 (b).

CANO, M. E.; CORDOVA-FRAGA, T.; SOSA, M.; BERNAL-ALVARADO, J.; BAFFA O. Understanding the magnetic susceptibility measurements by using an analytical scale. European Journal of Physics, London, v.29, p.345-354, 2008.

CANTARELLA, H.; QUAGGIO, J. A.; RAIJ, B. Van.; ABREU, M. F. Variability of soil analysis in commercial laboratories: implications for lime and fertilizer recommendations. Communications in Soil Science and Plant Analysis, London, v.37, p.2213-2225, 2006.

CARNEIRO, A. A. O.; TOUSO, A. T.; BAFFA, O. Avaliação da susceptibilidade magnética usando uma balança analítica. Química Nova, São Paulo, v.26, n.6, p.952-956, 2003.

CARVAlHO, L. A.; MEURER, I.; SILVA JUNIOR, C. A; CENTURION, J. F. Spatial variability of soil physical properties in two management systems in sugarcane crop. Engenharia Agrícola, Jaboticabal, v.32, n.1, p.60-68, 2012.

CHEVRIER, V.; MATHÉ P. E. Mineralogy and evolution of the surface of Mars: A review. Planetary and Space Science, Elmsford, v.55, p.289-314, 2007.

COEY, J. M. D. Magnetic properties of iron in soil iron oxides and clay minerals. In: STUCKI, J. W.; GOODMAN, B. A.; SCHWERTMANN, U. (eds.). Iron in soils and clay minerals. Dordrecht: Reidel Publishing Corporation, 1988. p.397-466.

CORTEZ, L. A.; MARQUES JR., J.; PELUCO, R. G.; TEIXEIRA, D. B.; SIQUEIRA, D. S. Suscetibilidade magnética para identificação de áreas de manejo específico em citricultura. Energia na Agricultura, Botucatu, v.26, p.60-79, 2011. 
DAVIS, R. S. Using small, rare-earth magnets to study the susceptibility of feebly magnetic metals. American Journal of Physics, New York, v.60, p.365-370, 1992.

DEARING, J. A. Environmental magnetic susceptibility: Using the Bartington MS2 system. 2nd. ed. Kenilworth: Chi Publishing, 1999. 54p.

EMBRAPA. Empresa Brasileira de Pesquisa Agropecuária. Manual de métodos de análise de solo. 2 ed. Rio de Janeiro, 1997. 212p.

EMBRAPA. Empresa Brasileira de Pesquisa Agropecuária. Centro Nacional e Pesquisa em Solos. Sistema brasileiro de classificação de solos. Brasilia: Embrapa-SPI; Rio de Janeiro: EmbrapaSolos, 2006. 306 p.

FABRIS, J. D.; COEY, J. M. D.; MUSSEL, W. N. Magnetic soils from mafic lithodomains in Brazil. Hyperfine Interactions, Brasil, v.113, p.249-258, 1998.

FERREIRA, M. M.; FERNANDES, B.; CURI, N. Influência da mineralogia da fração argila nas propriedades físicas de Latossolos da região Sudeste do Brasil. Revista Brasileira de Ciência do Solo, Viçosa-MG, v.23, p.515-524, 1999.

FONTES, M. P. F.; OLIVEIRA, T. S.; COSTA, L. M.; CAMPOS, A. A. G. Magnetic separation and evaluation of magnetization of Brazilian soils from different parent materials. Geoderma, Amsterdam, v.96, p.81-99, 2000.

GARDNER, W. H. Water content. In: KLUTE, A. (Ed.). Methods of soil analysis. Madison: American Society of Agronomy, 1986. p.493-544.

GRIMLEY, D. A.; VEPRASKAS, M. J. Magnetic Susceptibility for Use in Delineating Hydric Soils. Soil Science Society American Journal, Madison, v.64, p.2174-2180, 2000.

HANESCH, M.; SCHOLGER, R. The influence of soil type on the magnetic susceptibility measured throughout soil profiles. Geophysical Journal International, Oxford, v.161, p.50-56, 2005.

HANESCH, M.; STANJEK, H.; PETERSEN, N. Thermomagnetic measurements of soil iron minerals: The role of organic carbon. Geophysical Journal International, Oxford, v.165, p.53-61, 2006.

HARTEMINK, A. E. El futuro Del La ciência Del suelo.Wageningen: Intenational Union of Soil Science, 2007. 165p.

HEREDIA, O. S.; CIRELLI, A. F. Environmental risks of increasing phosphorus addition in relation to soil sorption capacity. Geoderma, Amsterdam, v.137, p.426-431, 2007.

JOHNSON, S. E.; LOEPPERT R. H. Role of organic acids in phosphate mobilization from iron oxide. Soil Science Society American Journal, Madison, v.70, p.222-234, 2006.

KÄMPF, N.; CURI, N. Óxidos de ferro: indicadores de atributos e ambientes pedogenênicos e geoquímicos. In: NOVAIS, R. F.; ALVAREZ, V. V. H.; SCHAEFER, C. E. G. R. (Eds). Tópicos em Ciência do Solo. Viçosa: Sociedade Brasileira de Ciência do Solo, 2000. p.107-138.

KEMPER, W. D.; CHEPIL, W. S. Size distribution of aggregates. In: BLACK, C. A. (Ed). Methods of soil analysis. Madison: American Society of Agronomy, 1965. p.499-510.

LUQUE, E. C. L. Propiedades magnéticas de los óxidos de hierro en suelos mediterráneos. 2008. 179 f. Tese (Doutorado) - Escuela Técnica Superior de Ingenieros Agrónomos y de Montes, Universidad de Córdoba, Córdoba, 2008.

MAHER, B.A.; THOMPSON, R. The magnetic record of palaeoclimate in the terrestrial loess and palaeosol sequences, in Quaternary Climates. In: MAHER, B.A. \& THOMPSON, R. (Ed.).

Environments and Magnetism. Cambridge: University Press, 1999. p. 81-125. 
MATHÉ, V.; LÉVÊQUE, F.; MATHÉ, P. E.; CHEVALLIER, C.; PONS, Y. Soil anomaly mapping using a caesium magnetometer: Limits in the low magnetic amplitude case. Journal of Applied Geophysics, Amsterdam, v. 58, n. 3, p. 202- 17, 2006.

McBRATNEY, A. B.; MINASNY, B.; CATTLE, S. R.; VERVOORT, R. W. From pedotranfer functions to soil inference systems. Geoderma, Amsterdam, v.109, p.41-73, 2002.

PEDROTTI, A.; FERREIRA, M. M.; CURI, N.; SILVA, M. L. N.; LIMA, J. M.; CARVALHO, R. Relação entre atributos físicos, mineralogia da fração argila e formas de alumínio no solo. Revista Brasileira de Ciência do Solo, Viçosa-MG, v.27, p.1-9, 2003.

PREETZ, H.; ALTFELDER, S.; IGEL, J. Tropical Soils and Landmine Detection - An Approach for a Classification System. Soil Science Society American Journal, Madison, v.72, p.151-159, 2008.

RAIJ, B. van; ANDRADE, J. C.; CANTARELlA, H.; QUAGGIO, J. A. (Ed.) Análise química para avaliação da fertilidade de solos tropicais. Campinas: Instituto Agronômico, 2001. 285p.

RANKINE, A. O. A simple method of demonstrating the paramagnetism and diamagnetism of substances in magnetic fields of low intensity. Proceedings of the Physical Society, v.46, p.391, 1934.

REZENDE, M.; SANTANA, D. P.; RESENDE, S. B. Suscetibilidade magnética em Latossolos do sudeste e Sul do Brasil. In: Reunião de Classificação, Correlação de Solos e Interpretações de Aptidão Agrícola, 3., 1988, Rio de Janeiro. Anais... Rio de Janeiro: EMBRAPA SNLCS/ SECS, 1988. cap. 3, p. 233-258.

SANTOS, H. L.; MARQUES JUNIOR, J.; MATIAS, S. S. R.; SIQUEIRA, D. S.; PEREIRA, G. T. Suscetibilidade magnética na identificação de compartimentos da paisagem em uma vertente. Revista Brasileira de Ciências Agrárias, Belém, v.6, p.710-716, 2011.

SCHWERTMANN, U.; TAYLOR, R. M. Iron oxides. In: DIXON, J. B.; WEED, S. B. (Ed.) Minerals in soil environments. 2nd. ed. Madison: Soil Science Society of America, 1989. p.379438. (Book Series, 1).

SCHWERTMANN, U. Occurrence and formation of iron oxides in various pedoenvironments. In: STUCKI, J. W.; GOODMAN, B. A.; SCHWERTMANN, U. (Ed.). Iron in soils and clay minerals. Dordrecht: Reidel Publishing Corporation, 1988. p.267-308.

SIQUEIRA, D. S.; MARQUES JR., J.; MATIAS, S. S. R.; BARRÓN, V.; TORRENT, J.; BAFFA, O.; OLIVEIRA, L. C. Predicting the properties of Brazilian Haplustalfs from magnetic susceptibility measurements. Soil Use and Management, Oxford, v.26, p.425-431, 2010.

TORRENT, J.; LIU, Q.; BLOEMENDAL, J.; BARRÓN, V. Magnetic enhancement and iron oxides in the upper Luochuan loess-paleosol sequence, Chinese Loess Plateau. Soil Science Society American Journal, Madison, v.71, p.1-9, 2007.

ULÉN, B.; SNÄLL, S. Forms and retention of phosphorus in an illite-clay soil profile with a history of fertilization with pig manure and mineral fertilizers. Geoderma, Amsterdam, v.137, p.455-465, 2007.

WARRICK, A. W.; NIELSEN, D. R. Spatial variability of soil physical properties in the field. In: HILLEL, D. (ed.) Applications of soil physics. New York: Academic, 1980. p.319-344. 